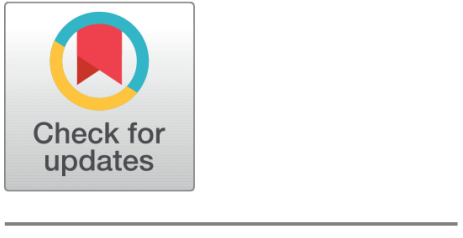

OPEn ACCESS

Received: 07.02.2021

Accepted: 29.07.2021

Published: 08.09.2021

Citation: Singh K, Jha R (2021) Critical appraisal of water quality model parameters for an urban city in lower Ganga basin during preand post-COVID19 Lockdown in India. Indian Journal of Science and Technology 14(29): 2439-2447. https ://doi.org/10.17485/IJST/v14i29.242

* Corresponding author.

rjha43@gmail.com

Funding: None

Competing Interests: None

Copyright: (c) 2021 Singh \& Jha. This is an open access article distributed under the terms of the Creative Commons Attribution License, which permits unrestricted use, distribution, and reproduction in any medium, provided the original author and source are credited.

Published By Indian Society for Education and Environment (iSee)

ISSN

Print: 0974-6846

Electronic: 0974-5645

\section{Critical appraisal of water quality model parameters for an urban city in lower Ganga basin during pre- and post-COVID19 Lockdown in India}

\author{
Kamakshi Singh ${ }^{1}$, Ramakar Jha ${ }^{2 *}$ \\ 1 Research Scholar, Department of Civil Engineering, NIT Patna, India \\ 2 Professor, Department of Civil Engineering, National Institute of Technology, Patna
}

\begin{abstract}
Objectives: To assess the impact of urban city Patna on water quality of the river Ganga during pre and post COVID-19 lockdown. Method: A study is done to assess the impact of point and nonpoint source pollution at different reaches of river Ganga for the years 2017 to 2020 (at a stretch of $40 \mathrm{~km}$ of a urban city in lower Ganga plains). A total of 450 datasets have been collected from eight river locations and two major drains. The equations of deoxygenation and reaeration coefficient used in water quality modelling have been tested for their applicability in the study area. Findings:Analysis of water quality data collected from 8 river locations and 2-drains for the year 2017-2020 shows significant improvement in water quality variables observed in river Ganga at Patna due to reduction in influx of point and non-point source pollution including floating population at Patna during COVID19 lockdown (March- June 2020). The use of BOD-DO developed by Streeter-Phelps (1925) as Oxygen-Sag curve is still valid, if input variables are limited. However, Camp (1963) and Jha et al. (2007) may be used effectively for comprehensive input data sets. Moreover, the refined model for predicting reaeration coefficient has been tested for the developed dissolved oxygen (DO) model and biochemical oxygen demand (BOD) model for pre- and post COVID19 lockdown individually. The water quality maps developed using satellite (Landsat-8) data provides the turbidity levels during pre and post COVID19 countrywide lockdown period and resulted in a significant improvement. Novelty: The study is unique due to water quality analysis during COVID19 and its comparison with previous year data. The deoxygenation and reaeration coefficients values are established for pre-and post COVID period. Also use of Landsat-8 data is used for assessing turbidity for pre- and post-COVID19.
\end{abstract}

Keywords: point source pollution; COVID 19; BODDO modelling; nonpoint pollution 


\section{Introduction}

In rivers or streams, good quality of freshwater is essential for the human being, flora, fauna and other living things ${ }^{(1-33)}$. Water possesses a unique property of dissolving and carrying a variety of substances with it $^{(1,1,2,2,3,3,4,6-8,8-10,10-12,12,13,13,13,14,14,14,15,15,15,16,16,16,17,17,17,18,18-21)}$. The river water acts as source of water for drinking, bathing, washing, and sink for huge loads of waste from industries, domestic sewage, and agriculture $^{(5,11,12,14,15,15-19,19,20,20,20,21,21,21,21,22,22,22,22,22,23,23,23,23,23,24,24,24,24,24,25,25,25,25,26,26,26,26,27,27,27,27,28,28,28,28,29,29,29,29,30,30,30,30,31,31,31,32,32-34)}$

The River Ganga, which is the most sacred river in India, has very high self-purification capacity due to it turbulent nature, dynamic behaviour, high reaeration process, and other related factors. Due to over exploitation of freshwater and disposal of waste water in River Ganga from mega and metro cities situated along the river Ganga, the water quality of river Ganga has been deteriorating in recent past. ${ }^{(6,7,9,11,15,19,19,20,20-22,22,23,23,23,24,24,25,25,25,26,26,26,27,27,27,28,28,28,29,29,30,30-33)}$. In most of the studies done in recent past, the variation of water quality parameters such as DO and BOD has been estimated. However, very little work has been done for water quality modelling and establishment of water quality parameters such as deoxygenation rate constant and reaeration coefficient during pre as well as post COVID period.

To assess the changes in water quality variables such as biochemical oxygen demand (BOD) and dissolved oxygen (DO) of river Ganga at different river locations in urban city of Patna, we need to consider the water quality modelling approach and establish model parameters. From the literature, it has been observed that BOD-DO modelling work started from the pioneering work of Streeter and Phelps $(1925)^{(4-29)}$, producing the classic dissolved oxygen sag model. Subsequent to Streeter and Phelps (1925). In the last three decades, several BOD-DO models were introduced ${ }^{(1,3,4,4,5,5,6,6,6,6,7,7,8,8,9,9,10,10,11,11,12,12,13,13,13,13,14,14,14,15,15,15,16,16,16,17,17,18,18,19,19,20,20,21,21-23,23-29,34) . ~ I t ~ i s ~ i n t e r e s t i n g ~ t o ~}$ note that most of these models have gradually increased in terms of the number of variables representing the variation of BOD as well as DO concentrations.

In general, the BOD-DO models, can be derived from Equation 1 as given below

$$
\begin{aligned}
\frac{\partial C}{\partial t}+v_{x} \frac{\partial C}{\partial x}+v_{y} \frac{\partial C}{\partial y}+v_{z} \frac{\partial C}{\partial z}= & \frac{\partial}{\partial x}\left(D_{x} \frac{\partial C}{\partial x}\right)+\frac{\partial}{\partial y}\left(D_{y} \frac{\partial C}{\partial y}\right) \\
& +\frac{\partial}{\partial z}\left(D_{z} \frac{\partial C}{\partial z}\right)+S(x, y, z, t) \pm S_{\text {internal }}
\end{aligned}
$$

The presence of dissolved oxygen (DO) in water is the primary criterion for the water quality of streams. To model streams and to allocate waste loads, use of the reaeration coefficient, $\mathrm{K}_{2}$, is essential for dissolved oxygen computation. The theoretical background to the reaeration coefficient is available in many studies ${ }^{(2-15,17)}$. The rate of mass transfer, $\mathrm{dD} / \mathrm{dt}$, of oxygen from the atmosphere to the body of the turbulent liquid generally is proportional to the difference between the existing concentration of dissolved oxygen, $\mathrm{D}$, and the equilibrium or saturation concentration of dissolved oxygen, $\mathrm{D}_{0}$, in the liquid. The mathematical expressions can written as

$$
\frac{\mathrm{d} D}{\mathrm{~d} t}=\left(K_{2}\right)_{T}\left[D_{0}-D\right]
$$

where $\left(\mathrm{K}_{2}\right)_{T}$ is the reaeration coefficient at test temperature $\mathrm{T}^{\circ} \mathrm{C}$. The value of $\left(\mathrm{K}_{2}\right)_{T}$ is related to the value $\left(\mathrm{K}_{2}\right)_{20}$ as follows

$$
\left(K_{2}\right)_{T}=\left(K_{2}\right)_{20} \times 1 \cdot 024^{(T-20)}
$$

In the present work the impact of point and non-point source pollution in the river Ganga at various locations of Patna town, Bihar, India has been assessed during pre- and post- COVID19 countrywide lockdown and predictive equations have been tested for their applicability in the River Ganga at Patna using data monitored and generated during field survey.

\section{The Study area}

The sampling locations in the study area of urban city Patna are shown in Figure 1, which includes 8 river locations and two drains. They are (1) Sherpur, (2) Panapur, (3) Digha Drain (4) Nakta Diara, (5) Rajapur Drain, (6) Gandhi Maidan, (7) Gandhi Ghat, (8) Gandhi Setu, (9) Sabalpur, and (10) Jethuli Ghat. The data of previous years for the same period and at same locations have been obtained from Central Water Commission (CWC), Bihar State pollution control board (BSPCB) and Central Pollution Control Board (CPBC) India. 


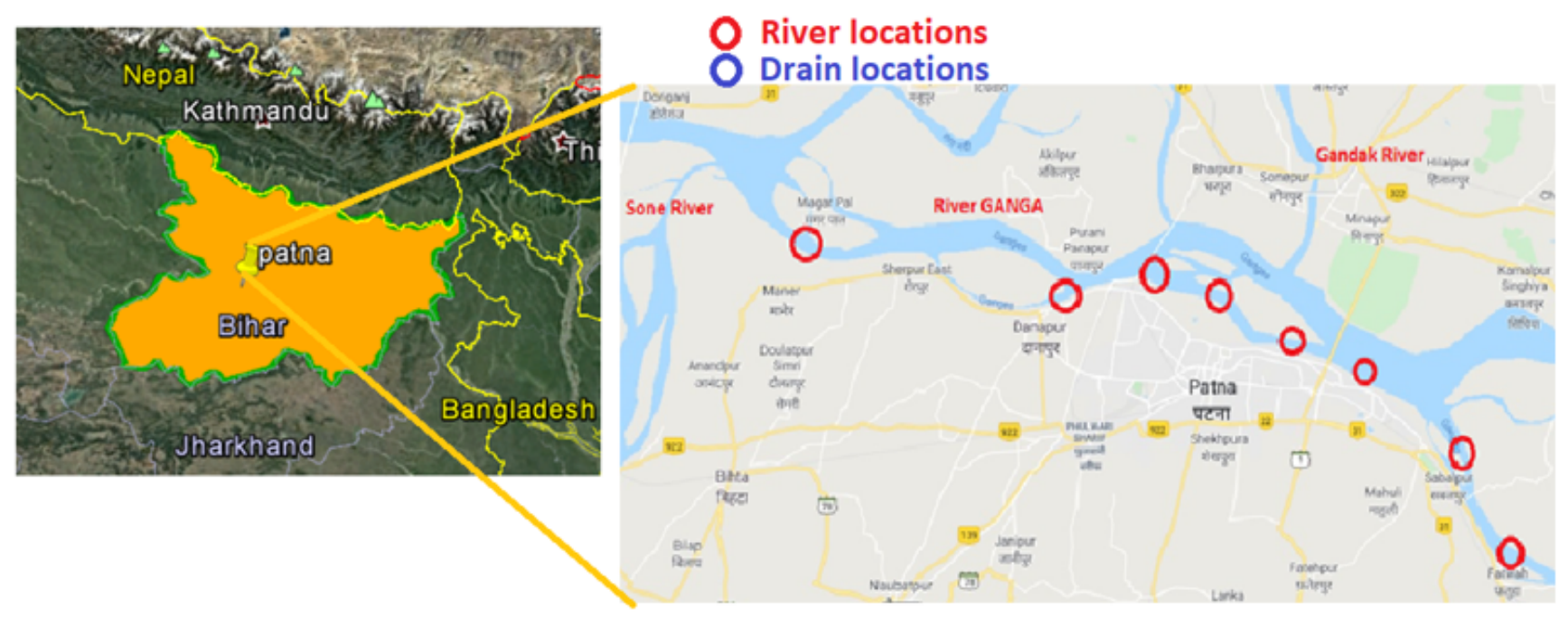

Fig 1. Water Quality sampling locations in River Ganga at Patna, Bihar, India

The population of Patna urban is about 17 lakhs and the floating population, which is coming to Patna for work and business is about 2 lakhs per day. The total wastewater generation is expected to be 320 MLD. It was found that the water quality of river Ganga has improved significantly during COVID19 lockdown, so the study which was done during the years 2017-2019 was extended to the year 2020 .

\section{Methodology}

\subsection{Water Quality Data sampling}

The water samples (either collected from ground locations or obtained from different government agencies) of the river Ganga at urban areas of Patna city. All the samples collected from 10 locations were stored and preserved without delay inside acidcleaned polypropylene bottles during frozen condition using transportable ice box to reduce the biogeochemical alterations as per standard procedure ${ }^{(1-4)}$. The Standard method for water samples and IS Codes for water quality testing was used to analyse $\mathrm{pH}$, water temperature, dissolved oxygen (DO), and biochemical oxygen demand (BOD).

\subsection{Biochemical oxygen demand (BOD) and Dissolved oxygen (DO) Models}

In India, limited river water quality modelling efforts have been made during the recent past for BOD and DO simulations $^{(1,3,4,4,5,5,6,6,6,6,7,7,8,8,9,9,10,10,11,11,12,12,13,13,13,13,14,14,14,15,15,15,16,16,16,17,17,18,18,19,19,20,20,21,21-23,23-29,34)}$.

In the present work, the most commonly used models have been tested for their applicability in urban city Patna situated along river Ganga for BOD and DO simulation. (Table 1$)^{(13,34)}$.

The performance evaluation using standard error, mean multiplicative error, and correlation coefficient of form of simplified form of refined models for BOD and DO simulations has been done. ${ }^{(13,34)}$

Various model parameters are used for BOD and DO modelling. The deoxygenation rate constant, K1 (L/day), was determined from the BOD values and estimated travel time of river reaches. In this approach, the BOD values obtained for different reaches of the River Ganga were plotted on a log scale ( $\mathrm{Y}$ axis) and the travel time is plotted on a normal scale (X axis). The slope of the line provides the values of the deoxygenation coefficient $\left(\mathrm{K}_{1}\right)$. The reaeration coefficient $\left(\mathrm{K}_{2}\right)$ was computed using the Froude number approach proposed by Jha et al. (2004). The equation is

$$
K_{2}=0.603286 V^{0.4} S^{-1.0} H^{0.154} \quad \mathrm{Fr} \leqslant 1
$$


Table 1. BOD and DO models used for the water quality simulation in river Ganga at Patna

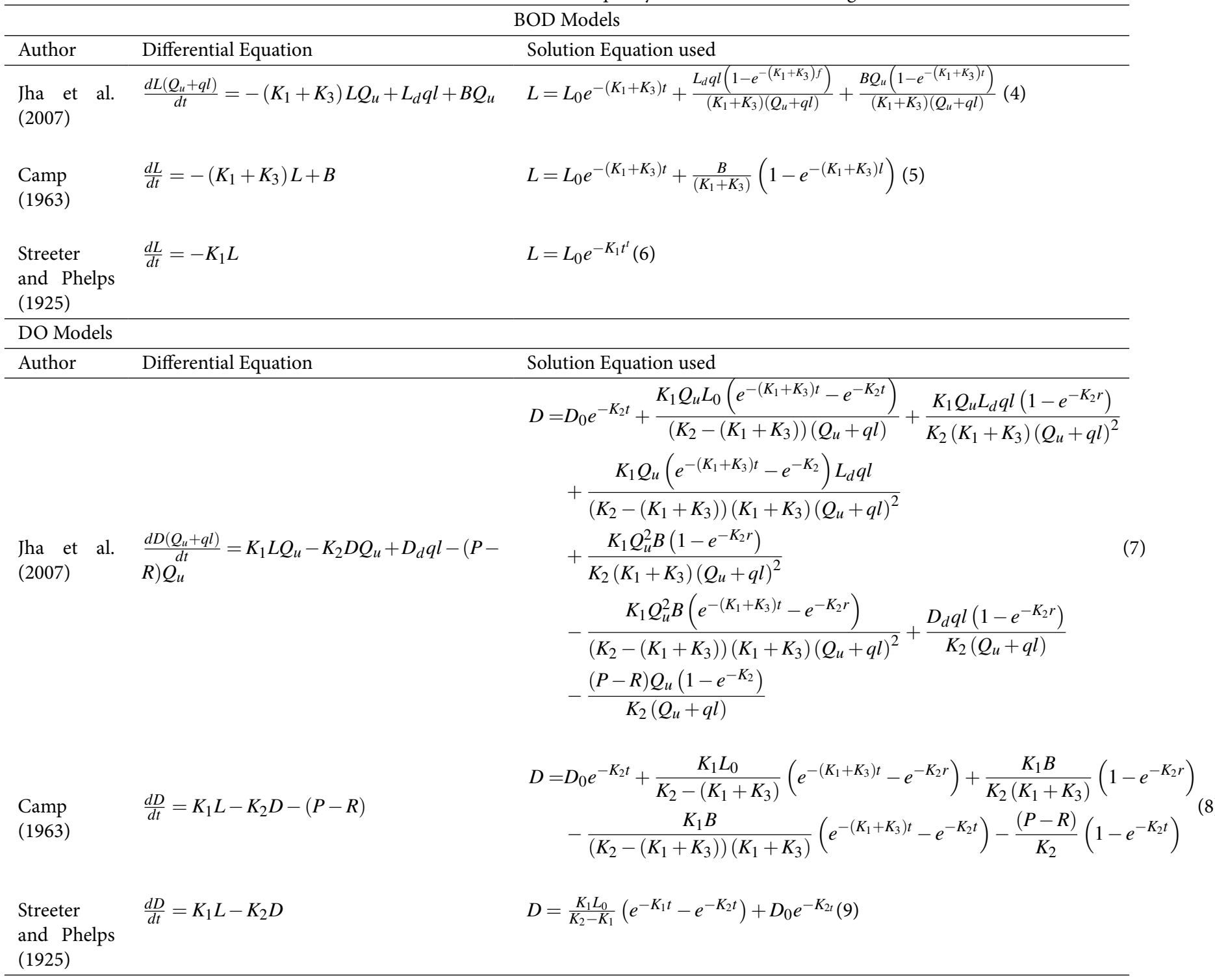

\section{Results and Discussion}

\subsection{Analysis of Water Quality Data}

The water quality samples collected from different locations indicate variation in their values due to influx of point source pollution (Figures 2 and 3 ). The analysed data have been utilised for water quality modelling and establishing different parameters $\mathrm{K}_{1}$ and $\mathrm{K}_{2}$ in BOD-DO modelling. It is observed from Figure 2 that the DO values are 7.6 to $8.4 \mathrm{mg} / \mathrm{l}$ and BOD values are varying between 1 to $2.5 \mathrm{mg} / \mathrm{l}$ during lockdown period. The BOD and DO values collected for the years 2017, 2018 and 2019 indicates DO values are lower than the lockdown period in the year 2020.

Further, to demonstrate the water quality status of River Ganga along the urban areas of Patna city, turbidity maps of the month pf April for the years 2017-2020 were analysed using Landsat-8 data. Figure 3 illustrates the water quality (turbidity) maps during the years 2017-2020. It is interesting to see that, during COVID19 countrywide lockdown period, water quality of river Ganga at Patna improved significantly, not only in terms of BOD and DO, but also I terms of turbidity due to reduction in waste water from point source pollution (municipal drains and industrial drains) as well as non-point source pollution. 


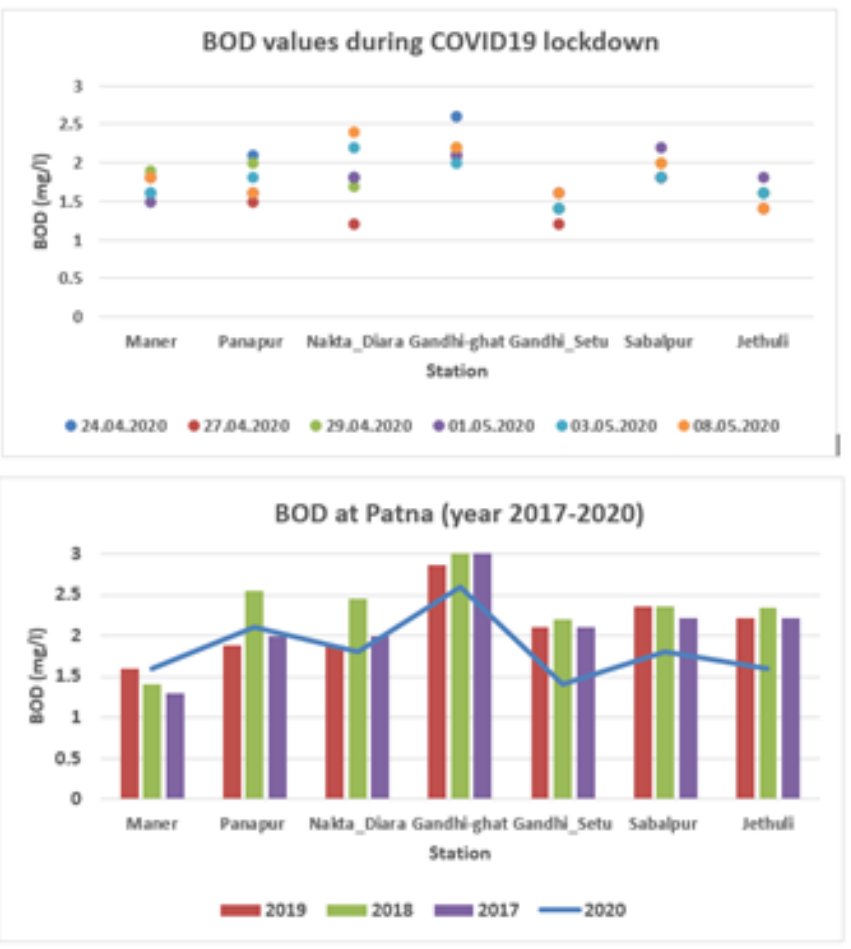

Fig 2. BOD observed at different locations of River Ganga

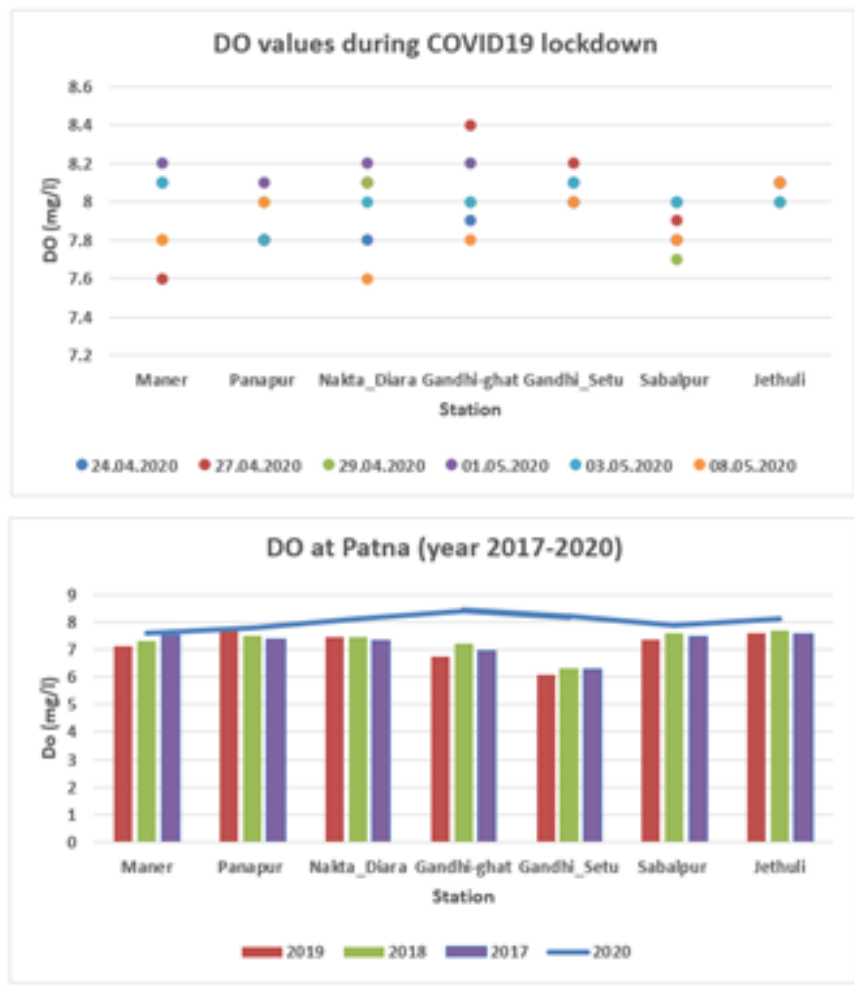

Fig 3. DO observed at different locations of River Ganga 


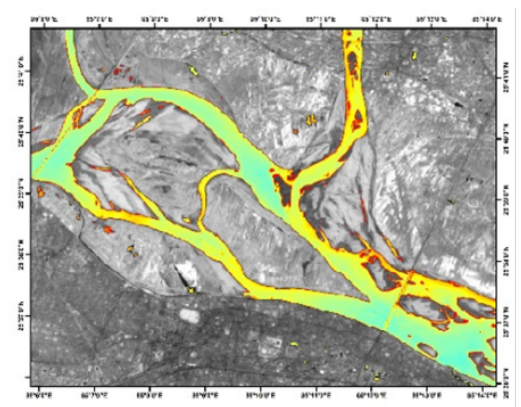

(a) April 2017

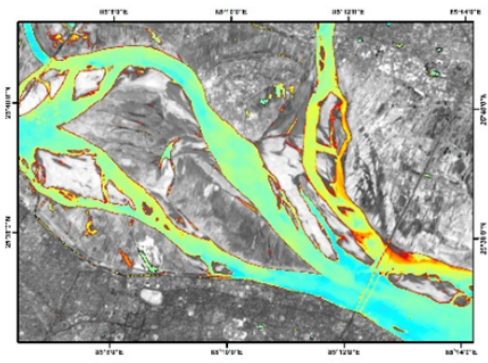

(c) April 2019

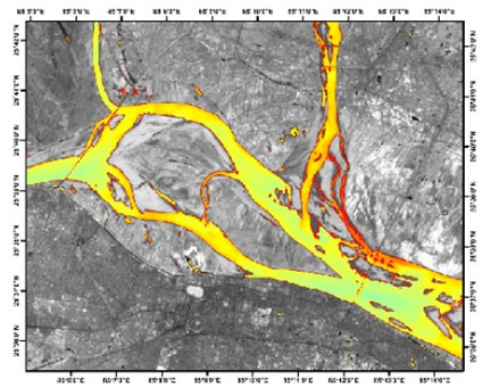

(b) April 2018

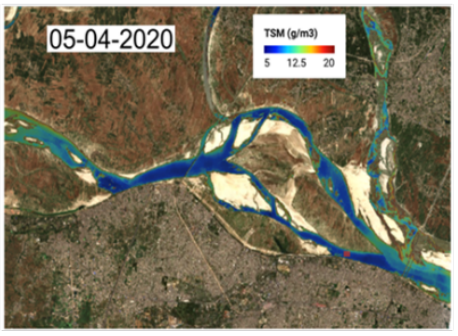

(d) April 2020

Fig 4. Plates showing improvement in water quality of river Ganga at Patna during COVID 19 country wide Lockdown in the year 2020

\subsection{Analysis of results using BOD-DO Modelling approach}

The input parameters, required by these models for BOD and DO simulations, as given in Table 2 were estimated using methods described earlier and equation (10) above. It has been observed that the BOD and DO rate constants are too different during pre- and post-monsoon period. From Table 2(a) provides the values of deoxygenation rate constants (ranging between 0.25 to 0.45 ) and reaeration coefficient values (ranging between 3.6- to 5.1) during pre-COVID period, when the river was highly polluted due to influx of point and non-point source pollution. Table 2(b) provides the values of deoxygenation rate constants (ranging between 3.5 to 6.5) and reaeration coefficient values (ranging between 6.25 to 9.5) during post-COVID period, which was during lockdown period. Significant improvement observed in both the constants.

For BOD and DO modelling, Table 2 data were used. It has been observed that the results obtained using the Camp (1963) model provides better results for River Ganga in comparison to the Streeter-Phelps (1925) model (Figures 4 and 5 ). The findings show that after the entry of sewage in River Ganga, its colloidal materials were quickly coagulated and removed. As a result, the BOD was found to decrease at a faster rate at different locations in River Ganga. The model developed by Jha et al. (2007) is found to be versatile and could not be used due to insufficient data availability obtained from different sources.

Table 2. Model Parameter Considered for Models

\begin{tabular}{llll}
\hline Reach No. & Name of the reach & Deoxygenation rate constant (K1) & Reaeration Coefficient (K2) \\
\hline 1 & Maner-Panapur & 0.45 & \\
2 & Panapur-Drain 1 & 0.45 & \\
3 & Drain 1- Nakta Diara & 0.30 & As per equation (10) shown \\
4 & Nakta Daira-Drain 2 & 0.30 & above \\
5 & Drain 2- Gandhi Maidan & 0.25 & \\
6 & Gandhi Maidan-Gandhi ghat & 0.25 & 0.35 \\
7 & Gandhi ghat- Gandhi Setu & 0.45 & \\
8 & Gandhi Setu-Sabalpur & 0.45 & \\
9 & Sabalpur- Jethuli &
\end{tabular}




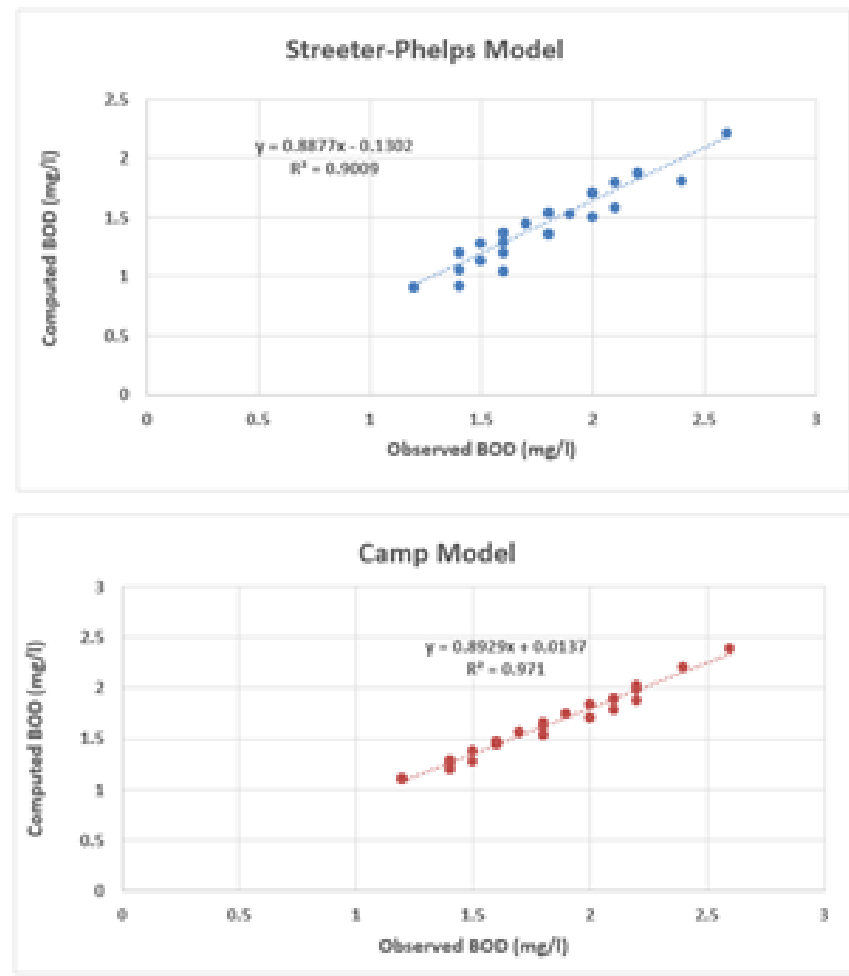

Fig 5. BOD modelling results at downstream reaches

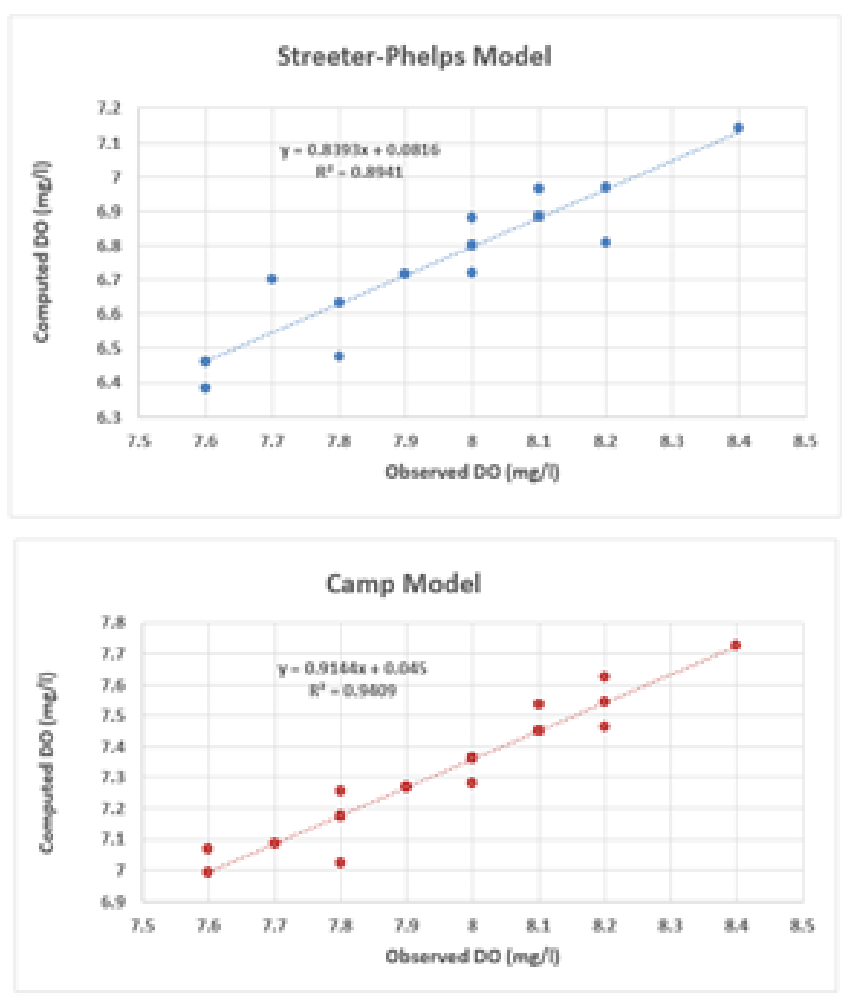

Fig 6. DO modelling results at downstream reaches 


\section{Conclusions}

The following Conclusions are drawn:

1. Significant improvement in water quality variables is observed in river Ganga at Patna due to reduction in influx of point and non-point source pollution including floating population. The values of deoxygenation rate constant and reaeration rate coefficients are found to be very high during lockdown period indicating quick decay process and more aeration due to high velocity and high discharge.

2. The use of BOD-DO developed by Streeter-Phelps (1925) as Oxygen-Sag curve is still valid, if input variables are limited. However, Camp (1963) and Jha et al. (2007) may be used effectively for comprehensive input data sets.

3. The water quality maps developed using satellite (Landsat-8) data provides the turbidity levels during pre and post COVID19 countrywide lockdown period and resulted in a significant improvement.

\section{References}

1) Apha, Standard. Methods for the Examination of Water and Wastewater 16th Edn. Washington, DC. American Public Health Association. 1985. Available from: https://agris.fao.org/agris-search/search.do?recordID=US19890081964.

2) Jha R, Ojha C, Bhatia K. Refinement of predictive reaeration equations for a typical India river. Hydrological Processes 2021;15.

3) Jolankai G. Basic river water quality models, IHP-V, Technical documents in hydrology no. Paris. UNESCO. 1997. Available from: https://hydrologie. org/BIB/Publ_UNESCO/TD_013_1997.pdf.

4) Streeter HW, Phelps EB. A study of the pollution and natural purification of the Ohio river. Public Health Service. 1925;(146).

5) Wang C, Sun N, Yeh WW. An upstream weight multiple-cell balance finite-element method for solving three dimensional convection-dispersion equations. Water Resources Research. 1986;22(11):1575-1589.

6) Adrian DD, Roider EM, Sanders TG. Oxygen Sag models for multi order biochemical oxygen demand reactions. Journal of Environmental Engineering. 2004;130(7):733-9372.

7) Alshawabkeh A, Adrian DD. 1997. Available from: https://doi.org/10.1016/S0043-1354(96)00384-3.

8) Ambrose RB, Barnwell TO, Mccutcheon SC, Williams JR. Chapter 14: Computer models for water quality analysis. In: Water Resources Handbook, L.W. Mays. McGraw-Hill. 1996.

9) Dogan E, Sengorur B, Koklu R. Modeling biological oxygen demand of the Melen River in Turkey using an artificial neural network technique. Journal of Environmental Management. 2009;9(2):1229-1235.

10) Ghosh NC, Mcbean EA. 1998. Available from: https://ink.springer.com/article/10.1023/A:1004912216834.

11) Soumyashree K, Rathore VS, Ray PK, Champati S, Richa, Swain SK. Classification of river water pollution using Hyperion data”. Journal of Hydrology. 2016;537:221-233.

12) Koussis AD, Kokitar P, Menta R. Modelling DO concent- rations in streams with dispersion. Journal of Environmental Engineering. 1990;116(3):601-614.

13) Moog DB, Jirka GH. Analysis of reaeration equations using mean multiplicative error. Journal of the Environmental Engineering Division. 1998;112(2):7339372.

14) Basant N, Gupta S, Malik A, Singh KP. 2010. Available from: https://doi.org/10.1016/j.chemolab.2010.08.005.

15) Hasan N, Prasad R. A Study of Water Pollution of River Ganga During Lockdown Period. Uttar Pradesh Journal of Zoology. 2021;42(5):32-39.

16) Jain CK. Application of chemical mass balance to upstream/ downstream river monitoring data. Journal of Hydrology. 1996;182:105-115.

17) Jha R, Ojha CSP, Bhatia KKS. A supplementary approach for estimating reaeration coefficients. Hydrological Processes. 2004;18:65-79.

18) Sattari MT, Joudi AR, Kusiak A. Estimation of water quality parameters with data-driven model. Journal American Water Works Association. 2016;108:232239.

19) Vinod T, Singh YAV, Purnendu B. Elsevier. 2003. Available from: https://doi.org/10.1016/s0043-1354(01.

20) Thomann RV, Muller JA. Principles of surface water quality modelling and control. New York. Harper and Row Publisher. 1987. Available from: https://www.worldcat.org/title/principles-of-surface-water-quality-modeling-and-control/oclc/569989609.

21) Genuchten MTV, Alves WJ. Analytical solutions of the one-dimensional convective-dispersive solute transport equation. Agricultural Research Service. 1982;(84):90020-90029.

22) Yu FX, Adrian DD, Singh. Modelling river quality by the superposition method. Journal Environment Systems. 1991;20(4):90204-90210.

23) Bhargava DS. Most rapid BOD assimilation in Ganga and Yamuna rivers. Journal of Environmental Engineering. 1983;109(1):1-174.

24) Dimri DD, Achlesh, Kumar, Ambika, Sharma A. Monitoring water quality of River Ganga using multivariate techniques and WQI (Water Quality Index) in Western Himalayan region of Uttarakhand. India Environmental Nanotechnology, Monitoring \& Management. 2021;15.

25) Dutta V, Dubey D, Kumar S. 2020. Available from: https://doi.org/10.1016/j.scitotenv.2020.140756.

26) Kumar A, Taxak AK, Mishra, Saurabh, Pandey R. . Available from: https://doi.org/10.1016/j.eti.2021.101405.

27) Priya M, Malhotra S, Kumar J, Neeshma. Ganga River Water Pollution: A Review”. Asian Journal of Biochemical and Pharmaceutical Research. 2016;6(2):2231-2560.

28) Muduli PR, Kumar A, Kanuri VV. Water quality assessment of the Ganges River during COVID-19 lockdown. International Journal of Environmental Science and Technology. 2021.

29) Anju P, Sapana B, Sourabh D, Ashok A, Asha B, Santosh R. Water Quality Assessment of River Ganga using Remote Sensing and GIS Technique. International Journal of Advanced Remote Sensing and GIS. 2015;4(1):1253-1261.

30) Shikha S, Arijit R, Madhoolika A. Springer. 2016. Available from: https://doi.org/10.1007/s11356-016-7411-9.

31) Sharma M, Krishna H, Agrahari P, Saha D. Water quality modeling studies of River Ganga in Kanpur stretch: Estimation of nonpoint source. In: Proceedings, ICIWRM-2000. .

32) Singh K, Jha R. Assessment of water quality in River Ganga at Patna, India. Hydraulics, Water Resources and Coastal Engineering: Groundwater and water quality;vol. 5. Jha R, Singh VP, Singh V, Roy LB, T R, editors;USA Book. Springer. 2021. Available from: http://10.1007/978-3-030-64202-0. 
33) Singh K, Jha R. Water quality of river Ganga using remote sensing and GIS techniques - a review. In: ASCE Conference. 2020.

34) Jha R, Ojha CSP, Bhatia KKS. Development of refined BOD and DO models for highly polluted Kali river in India. Journal of Environmental Engineering. 2007;133(8)8):733-9372. 